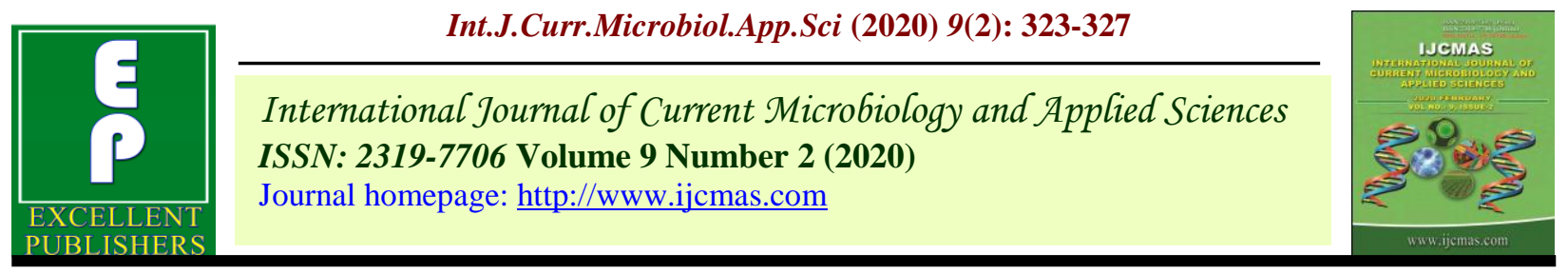

Original Research Article

https://doi.org/10.20546/ijcmas.2020.902.041

\title{
Evaluation of Cluster Frontline demonstrations in Enhancement of Black Gram (Vigna mungo L.) Production in Tribal Area of Madhya Pradesh
}

\author{
S.S Chouhan ${ }^{1}$, K.S. Kirar ${ }^{1}$, S.S Dhakad ${ }^{2 *}$ and J.S Rajpoot $^{1}$ \\ ${ }^{1}$ Krishi Vigyan Kendra (RVSKVV) Dhar (MP)-454001, India \\ ${ }^{2}$ Krishi Vigyan Kendra (RVSKVV) Shajapur, (MP)-465001, India \\ *Corresponding author
}

\section{Keywords}

CFLDs, black gram, Extension gap, Technology gap.

\section{Article Info}

Accepted:

05 January 2020

Available Online:

10 February 2020

\section{A B S T R A C T}

The front line demonstration of black gram were conducted during the rainy season at 50 farmer's field to determine the production potential and economic benefit of improved technologies consisting suitable variety (PU-31), integrated nutrient management (20:50:20 kg N:P:K /ha + Rhizobium + P.S. B.@ 5 g per kg of seed) integrated pest management-Deep ploughing + seed treatment with Rhizobium + Quniolphos @ 1.5 lit/ha) at Dhar district of Madhya Pradesh (India) during kharif season of 2016-17 \& to 2017-18. The results of demonstrations showed that farmers could increase the black gram productivity notably by switching over to improved variety and adoption of improved production technology. The improved technologies recorded mean yield of $11.06 \mathrm{q} / \mathrm{ha}$, which was 32.47 percent higher than that obtained with farmers practices of $8.38 \mathrm{q} / \mathrm{ha}$, The additional cost of Rs 1300 to 2350 gave additional net return, it was ranged Rs 7805 to Rs 11350 per hectare with increase benefit: cost ratio ranged from 1:3.9 to $1: 4.1$. The extension gap ranging between 2,55 to $3.00 \mathrm{q} / \mathrm{ha}$. Data on technology index reduced from 12.91 to $4.16 \%$, exhibited the feasibility of technology demonstration in this region. It can be concluded that the pulses production could be enhanced by encouraging the farmers through adoption of recommended technologies which were followed in the CFLDs.

\section{Introduction}

Historically India is the largest producer, consumer and importer of pulses. Pulses are a good and chief source of protein for a majority of the population in India. Protein malnutrition is prevalent among men, women and children in India. Pulses contribute 11\% of the total intake of proteins in India (Reddy, 2010). India is the world's largest producer as well as consumer of black gram. It produces about 1.5-1.9 MT of black gram annually from about $3.5 \mathrm{~m}$ ha .of area, with an average productivity of $600 \mathrm{~kg} / \mathrm{ha}$. Black gram output accounts for about 10 per cent of India's total pulse production. 
It is therefore, necessary to assess the technological gap in production and also to know the problems and constraints in adopting modern black gram production technologies Islam et al (2011).Black gram (Vigna mungo L.) belongs to family Fabaceae sub family papilionaceae, is being grown as one of the principle pulse crop.

In Madhya Pradesh is occupies in area of 0.64 million ha with the production and productivity of $0.26 \mathrm{MT}$ and $413 \mathrm{~kg} / \mathrm{ha}$ respectively. In India black gram is a grown in 3.11 million ha area with total production of $1.90 \mathrm{MT}$ and average productivity is 642 $\mathrm{kg} / \mathrm{ha}$ (Anonymous 2013). The most important states for pulses are Madhya Pradesh, Uttar Pradesh, Maharashtra, Andhra Pradesh, Karnataka and Bihar which together account for $80 \%$ of total production.

The decreasing per capita availability of pulses from $69 \mathrm{~g}$ in 1961 to $37 \mathrm{~g}$ in 2011 in the country has been a serious concern. To alleviate protein energy malnutrition, a minimum of $50 \mathrm{~g}$ pulses/capita/day should be available in addition to other sources of protein such as cereals, milk, meat and eggs.

India grow nearly 24 million hectare pulse crops and produce nearly 15.9 million tonnes of pulses grain, which is still deficit of the present consumption, i.e. 17.65 million tonnes (Ali and Kumar, 2008). They also stated that At least 29.30 million tonnes of pulses are required by 2020 .

Keeping this in view, the present investigation was undertaken to study the level of knowledge of farmers regarding black gram cultivation, extent of adoption of improved practices, to out the yield gap in black gram production technology. The present study was undertaken to evaluate the difference between demonstrated technologies through CFLDs demonstration vis-a-vis practices followed by the local farmers.

\section{Materials and Methods}

The improved technologies included improved variety (PU-31), integrated nutrient management (20:50:20 kg N:P:K /ha) + Rhizobium \& P.S.B. @ 5g per kg of seed, integrated pest management- Deep ploughing + Profenophos@1.5 Lit/ha)were tested under the demonstration.

Deep ploughing was done during the April month. Crop was sown between 06 to 09 July with a spacing of $30 \mathrm{~cm} \mathrm{x} 10 \mathrm{~cm}$ and seed rate was $20 \mathrm{~kg} / \mathrm{ha}$. An entire dose of $\mathrm{N}$ and $\mathrm{P}$ through Di ammonium Phosphate \& murate of potash was applied as basal before sowing, Farmer practice constituted no deep ploughing was done during summer, old variety of T-9 seed was used with higher seed rate $40 \mathrm{~kg} / \mathrm{ha}$, no seed treatment, no bio fertilizer rand imbalance use of fertilizer (18:46:0 NPK( kg/ha) were adopted.

Before conducting FLDs a list of farmers was prepared from group meeting and specific skill training was imported to the selected farmers regarding different aspect of cultivation. All other step like site selection, farmer selection, layout of demonstration, farmers participation etc were followed as suggested by Choudhary (1999).

Total 150 farmers were associated under this programme. The total area covered in 3 year was 60 hectares for demonstration of recommended improved practices of Black gram. In the demonstration one control plot was also kept where farmers practices was carried out .

A11 the production and protection technologies other than interventions were applied in similar manner in demonstrated as well as in farmers practices. 
The yield data was collected from the selected FLD farmers by random crop cutting method. The collected data were analyzed using simple tabular analysis like percentage etc.

The yield data were collected from both the demonstration and farmer's practices and their technology gap, extension gap, and technology index were a workout (Samui el al 2000) as given below.

(1) Technology gap = Potential yielddemonstration yield

(2) Extension gap = Demonstration yield - farmer's yield

(3) Technology Index

$$
=\frac{\text { Technology gap x } 100}{\text { Potential Yield }}
$$

\section{Results and Discussion}

The gap between the recommended practices and exiting farmer practices under black gram is presented in Table 1. Full gap was observed in case of variety, seed rate, seed treatment, and partial gap was observed in fertilizer and plant protection.

Table.1 Difference between recommended practices and existing farmer practices under chickpea FLD

\begin{tabular}{|l|l|l|l|}
\hline $\begin{array}{l}\text { Crop } \\
\text { operations }\end{array}$ & Recommended practices & Farmers practice & gap \\
\hline Variety & PU-31 & T-9 (Old) & Full gap \\
\hline $\begin{array}{l}\text { Land } \\
\text { preparation }\end{array}$ & $\begin{array}{l}\text { One deep ploughing with } \\
\text { soil turning plough and inter } \\
\text { cross ploughing. }\end{array}$ & $\begin{array}{l}\text { One cultivator } \\
\text { ploughing and two } \\
\text { inter cross } \\
\text { ploughing }\end{array}$ & Nil \\
\hline $\begin{array}{l}\text { Seed rate } \\
\text { (Kg/ha) }\end{array}$ & 20 & 40 & Full gap \\
\hline $\begin{array}{l}\text { Seed treatment } \\
\text { Rhizobium + PSB @ 5 gm/kg } \\
\text { seed }\end{array}$ & No seed treatment. & huge gap \\
\hline $\begin{array}{l}\text { Fertilizer dose } \\
\text { (Kg/ha) }\end{array}$ & DAP (100 Kg) & $\begin{array}{l}\text { 30x10 Row to row and plant to } \\
\text { plant Ridge and furrow }\end{array}$ & Line sowing \\
\hline $\begin{array}{l}\text { Sowing } \\
\text { method }\end{array}$ & $\begin{array}{l}\text { DAP (50 Kg) } \\
\text { gap }\end{array}$ \\
\hline
\end{tabular}


Table.2 Productivity, Extension Gap, Technology gap and technology index of chickpea as grown under FIB and existing package of practices.

\begin{tabular}{|c|c|c|c|c|c|c|c|c|c|}
\hline Year & $\begin{array}{c}\text { Area } \\
\text { in } \\
\text { ha }\end{array}$ & $\begin{array}{l}\text { No. of } \\
\text { Demo }\end{array}$ & $\begin{array}{c}\text { Potential } \\
\text { yield } \\
\left(\mathbf{q} / \mathbf{h a}^{-1}\right)\end{array}$ & $\begin{array}{r}\text { Y } \\
\text { R.P. }\end{array}$ & $\begin{array}{l}\text { ld } \\
\text { F.P. }\end{array}$ & $\begin{array}{c}\% \\
\text { increase } \\
\text { over F.P. }\end{array}$ & $\begin{array}{c}\text { Extensi } \\
\text { on gap } \\
\text { q ha' }\end{array}$ & $\begin{array}{c}\text { Technol } \\
\text { ogy gap } \\
\text { q/ha-1 }\end{array}$ & $\begin{array}{c}\text { Technolog } \\
\mathbf{y} \\
\text { Index }(\%)\end{array}$ \\
\hline 2015-16 & 20 & 50 & 12.00 & 10.45 & 7.90 & 33.55 & 2.55 & 1.55 & 12.91 \\
\hline 2016-17 & 20 & 50 & 12.00 & 11.25 & 8.75 & 28.57 & 2.50 & 0.75 & 6.25 \\
\hline 2017-18 & 20 & 50 & 12.00 & 11.50 & 8.50 & 35.29 & 3.00 & 0.50 & 4.16 \\
\hline Total/Mean & 60 & 50 & 12.00 & 11.06 & 8.38 & 32.47 & 2.68 & 2.35 & 7.77 \\
\hline
\end{tabular}

Table.3 Economic analysis of demonstration and farmers practices

\begin{tabular}{|c|c|c|c|c|c|c|c|c|c|}
\hline \multirow[t]{2}{*}{ Year } & \multicolumn{2}{|c|}{$\begin{array}{c}\text { Cost of } \\
\text { cultivation }\end{array}$} & \multicolumn{2}{|c|}{ Gross return } & \multicolumn{2}{|c|}{ Net return } & \multirow[t]{2}{*}{$\begin{array}{l}\text { Additional } \\
\text { cost }\end{array}$} & \multirow[t]{2}{*}{$\begin{array}{l}\text { Additional } \\
\text { net return }\end{array}$} & \multirow[t]{2}{*}{$\begin{array}{l}\text { B:C } \\
\text { ratio }\end{array}$} \\
\hline & RP & F.P. & R.P. & F.P. & R.P. & FP & & & \\
\hline $2015-16$ & 1050 & 8150 & 41800 & 31600 & 31300 & 2345 & 2350 & 7850 & 3.9 \\
\hline 2016-17 & 1135 & 8150 & 66625 & 31800 & 55275 & 2365 & 3200 & 11350 & 3.9 \\
\hline 2017-18 & 9800 & 8500 & 39870 & 28000 & 30070 & 1950 & 1300 & 10570 & 4.1 \\
\hline Mean & 10550 & 8267 & 49432 & 30467 & 38882 & 22200 & 2283 & 9923 & 4.0 \\
\hline
\end{tabular}

\section{Seed yield}

The yield of Black gram obtained over the year under improved technology as well as local check are presented in Table 2.The productivity of chickpea ranged from 10.45 to $11.50 \mathrm{q} / \mathrm{ha}$ with mean yield of $11.06 \mathrm{q} / \mathrm{ha}$ under improved technology on farmers field as against a yield ranged from 7.90 to 8.75 $\mathrm{q} / \mathrm{ha}$ with a mean of $8.38 \mathrm{q} / \mathrm{ha}$ recorded under farmers practice.

The higher productivity following recommended practices as well as farmer practice was during the year 2017-18, which might be due to continuous use of IPNM (Integrated Pest and Nutrient Management) practices. The higher yield of chickpea under recommended practices was due to the use of latest high yielding variety, integrated nutrients management and pest management Similar findings were reported by Kirar et al. (2006), Singh et al (2014).

\section{Economic}

The input and output prices of commodities prevailed during each year of demonstration were taken for calculating cost of cultivation, net return and benefit cost ratio (Table 3). The net return from recommended practices was Rs 16210 to Rs 19625 while the net return from farmer practices was Rs 12180 to Rs 14330. It means that net return from demonstration was higher than the farmer.

This finding is in corroboration with the findings of Dhakad et al, Mokidue et al, (2011) and. Raj et al (2013). The frontline demonstration (FLDs) plays a very important role to disseminate the recommended technology because it shows the potential of technologies resulting, which motivate the farmers for adopting theses technology.

Many farmers approached the FLD farmers to purchase the high yielding variety seed of 
blackgram and now the area under these varieties \& package of practices have increased which will spread in the adjoining village as well as other area in the district. These practices may be popularized in this area by the extension agency to bridge the higher extension gaps.

\section{References}

Ali M and Kumar S. 2008. Pulse crops of India In:The Hindu Survey of Indian Agriculture. Ernaculam malyalam manorma, pp 43-46.

Anonymous. 2013. Agricultural census, Directorate of economics and Statistics, Deptartment of Agriculture and Cooperation, Government of India.

Choudhary, B N. 1999. Krishi Vigyan Kendra-A guide for KVK managers. Publication, Division of Agricultural Extension, ICAR; 73-78

Dhakad, S.S., K.P. Asati, S.S. Chouhan, A.K. Badaya, K.S. Kirar and Ambawatia, G.R. 2018. Impact of Front Line Demonstration on the Yield and Economics of Chickpea (Cicer arietinum L.) in tribal area of Madhya Pradesh, India. Int.J.Curr.Microbiol.App.Sci. $\quad 7(05)$ : 3662-3666
Islam M, Mohanty A K and Kumar S (2011). Correlation growth yield and adoption of urdbean technologies. Indian Res $J$ Ext Edu 11 (2): 20-24.

Kirar, B.S.; Narshine, R.; Gupta, A.K. and Mukherji, S.C. 2006. Demonstration: An effective tool for increasing the productivity of Urd. Ind.Res.J. of Ext. Edu.,6(3):47-48

Mokidue I, Mohanty AK. and Sanjay, K 2011) Correlating growth, yield and adoption of urd bean technologies. Indian J. Ex. Edu. 11(2): 20-24.

Reddy AA 2010. Regional Disparities in Food Habits and Nutritional intake in Andhra Pradesh, India, Regional and Sectoral Economic Studies Vol. 10-2.

Samui, S.K., Maitra, S., Roy, D.K., Mondal, A.K. and Saha, D. 2000. Evaluation of front line demonstration on groundnut (Arachis hypogea L.) in Sundarbans. J. of Indian Society of Coastal Agri. Re., 18(2): 180-183

Singh Dhananjai, A.K. Patel, M.S. Baghel, Alka Singh, A. K. Singh 2014. Technological Intervention for Reducing the Yield Gap of Chick Pea (Cicer Arietinum L.) in Sidhi District Of M.P. International Journal of Advanced Research in Management and Social Sciences ,3(3):117-122

\section{How to cite this article:}

Chouhan S.S, K.S. Kirar, S.S Dhakad and Rajpoot J.S. 2020. Evaluation of Cluster Frontline demonstrations in Enhancement of Black Gram (Vigna mungo L.) Production in Tribal Area of Madhya Pradesh. Int.J.Curr.Microbiol.App.Sci. 9(02): 323-327. doi: https://doi.org/10.20546/ijcmas.2020.902.041 